\title{
津波による衝撃波圧から持続波圧への 遷移過程と内部流速場の関係
}

\author{
水谷 夏樹1・宮島 昌弘2 \\ 1正会員 大阪産業大学教授 工学部都市創造工学科（干574-8530 大阪府大東市中垣内3-1-1） \\ E-mail:mizutani@ce.osaka-sandai.ac.jp \\ 2正会員 大阪産業大学専任講師 工学部都市創造工学科（†574-8530 大阪府大東市中垣内3-1-1） \\ E-mail:miyajima@ce.osaka-sandai.ac.jp
}

\begin{abstract}
本研究は，鉛直壁に衝突する陸上遡上津波の内部流速場を可視化計測し，波圧や水位の同時計測結果と 併せて，衝突流速が支配的となる衝撃波圧から浸水深が支配的となる持続波圧への遷移過程を明らかにし たものである．津波が鉛直壁に衝突すると鉛直壁と底面との隅角部において大規模な渦が発生する. 津波 の主流はその渦の上部を流れるようになるため, 底面付近は主流が直接衝突しなくなることから動圧分の 波圧が低下し, その時の打ち上がり水位による静水圧となる。一方, 渦の上部においては主流が角度をも って衝突することから，底面付近に生じる衝撃波圧よりは小さいものの衝撃波圧が発生することが分かっ た.また，鈶直壁によって打ち上がった水塊が落水する瞬間にすべての高さの波圧が極大值を持ち，その 時に水平波力が最大となる場合があることが分かった.
\end{abstract}

Key Words : tsunami, impact wave pressure, wave force, internal velocity field, large scale vortex

\section{1. 緒言}

陸上遡上津波による構造物への波力の算定は, 海岸保 全施設や沿岸部における電力施設, 津波避難施設の設置 のみならず，地形によっては一般家屋に対する補強に対

して極めて重要な意味を持つ。

津波による陸上構造物への作用波力に関する研究は, 従来から数多く行われており(例えば，松冨ら ${ }^{1)}$ ), 最近で は榊山2)によって波圧の無次元作用高さを表す係数 $\alpha$ Fr数によって説明できることが示され，有光ら ${ }^{3}$ は最大 波圧の鉛直分布を浸水深と衝突流速の運動量からなるモ デル式を提案している. 一方で, 津波が構造物に衝突し た後の流体運動は極めて複雑であることから，内部の流 体運動と時々刻々の波圧の発生メカニズムには不明な点 が多いのが現状である.

水谷ら行は，構造物に衝突する津波を高速度ビデオカ メラによって撮影し, 衝突後に打ち上がる水塊の流体運 動と波圧の発生状況を関連させて主に現象論について述 べた. しかしながら，波圧の発生が流体内部の速度場に 支配されることから，流体の表面運動を捉えても定性的 な議論から脱することができなかった.

そこで本研究では, 高精度な津波波力の算定モデルに 資するため, 構造物に衝突する津波の内部流速場を可視 化(PIV)計測し, 同時に計測された波圧の時間変化と併 せて内部流速場に対する波圧の発生メカニズムについて
明らかにする. 特に, 津波の先端が衝突することで生じ る衝撃波圧の状態から浸水深が支配的となる持続波圧の 状態一の遷移過程について内部流速場の変化から明らか にすることを目的とする.

\section{2. 実験方法の概要と実験条件}

実験は，図-1に示すように長さ $3.3 \mathrm{~m}$ ，幅 $0.4 \mathrm{~m}$ ，高さ $0.3 \mathrm{~m}$ の面ガラス張り水路の上流端に貯水タンクを設 置し，コンプレッサーでゲートを急開させて段波を発生 させた. 水路内に長さ $2.0 \mathrm{~m}$, 高さ $0.05 \mathrm{~m} の 1 / 40$ アクリル 製勾配を設置し, 勾配の終端に高さ $0.05 \mathrm{~m}$ の水平床を接 続した. 陸上構造物の模型は, 高さ $0.3 \mathrm{~m}$ で水路幅と同 じ幅のアクリル製鉛直壁を勾配の終端から $0.195 \mathrm{~m}$ 水平 床上に設置し，非越流状態の実験を行った。

鉛直壁の前面に計測断面を設定し，全ての計測をこの 断面内で行った. 計測断面は水路の手前の側壁から 0.05

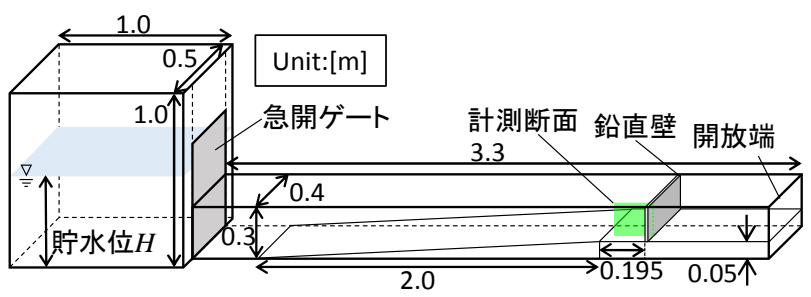

図-1 実験水槽の概要 


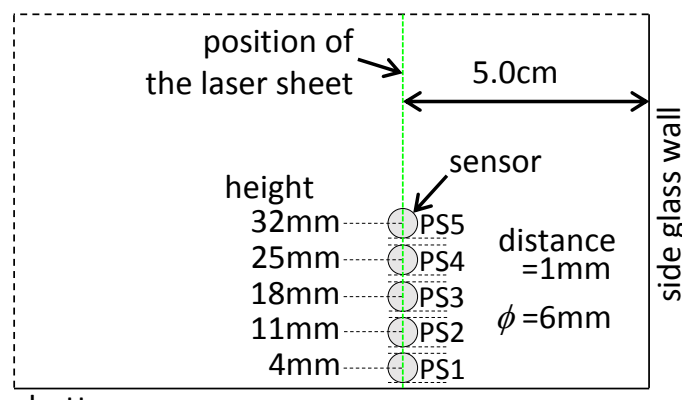

bottom

図-2 鉛直壁模型に設置された波圧センサの位置

表-1 実験条件と通過波の諸元

\begin{tabular}{c|c|c|c|c|c}
\hline $\begin{array}{c}\text { 貯水位 } \\
H[\mathrm{~cm}]\end{array}$ & $\begin{array}{c}\text { 最大水位 } \\
\eta_{\max }[\mathrm{mm}]\end{array}$ & $\begin{array}{c}\text { 最大流速 } \\
V_{\max }[\mathrm{m} / \mathrm{s}]\end{array}$ & $F r_{\max }$ & $\begin{array}{c}F r \\
\text { at } \eta_{\max }\end{array}$ & $\begin{array}{c}F r^{\prime}= \\
V_{\max } / \sqrt{g \eta_{\max }}\end{array}$ \\
\hline 6.0 & 9.7 & 0.514 & 2.04 & 1.16 & 1.67 \\
\hline 7.0 & 10.2 & 0.511 & 2.33 & 1.18 & 1.62 \\
\hline 8.0 & 13.7 & 0.684 & 2.97 & 1.14 & 1.87 \\
\hline 9.0 & 17.2 & 0.791 & 3.26 & 1.18 & 1.93 \\
\hline 10.0 & 19.6 & 0.911 & 3.56 & 1.21 & 2.08 \\
\hline 11.0 & 21.8 & 0.942 & 3.70 & 1.22 & 2.04 \\
\hline 12.0 & 24.4 & 1.011 & 3.67 & 1.05 & 2.07 \\
\hline
\end{tabular}

mの位置に設定し，圧力センサ(SSK製，P306V，定格容 量9.8kPa)を図-2のように，計測断面上で鉛直方向に $1 \mathrm{~mm}$ 間隔で5個設置した。本研究では，津波の先端が衝突す る衝撃波圧から持続波圧への遷移過程に着目寸るため, 底面付近の圧力変動を詳細に計測できるよう設置した。

津波波圧の計測は，サンプリング周波数 $10 \mathrm{kHz}$ で計測 し，100点の移動平均を用いてノイズを除去した.

一方, 内部流速場の計測は, 水路側方に高解像度カメ ラ(LaVision製，2560×2160 pixel)を設置し，水路底面より Yagレーザー(New Wave製)を照射して鉛直断面2次元PIV 計測を行った．鉛直壁前面の流体現象を詳細に可視化す るため，画角サイズを約 $90 \mathrm{~mm}$ に設定し，流速ベクトル の算出間距離を $0.28 \mathrm{~mm}$ とした. サンプリング周波数は レーザーの発光間隔である $15 \mathrm{~Hz}$ とした.

鉛直壁前面の水位の計測は，容量式波高計(ケネック 製，CHT-40)を用い，高さ0.05 mの水平床内にあらかじめ 水を貯めることができる容器を埋め込み，容量線とサポ 一トのみを露出させ， サンプリング周波数 $200 \mathrm{~Hz}$ で計測 を行った. 波高計を鉛直壁に最も近づけて設置したが, 容量線と鉛直壁との間隔は $5 \mathrm{~mm}$ である.

計測は同じ条件で3回ずつ行った。 まず，波圧とPIVの 同時計測を3回行い，次に波圧と水位の同時計測を3回行 っている．また，通過波の諸元を求めるため，鉛直壁位 置での水位とPIVの同時計測を3回行った.

表-1に実験条件と通過波の諸元を示す。ここで，Hは 貯水タンク内での初期貯水位であり， $\eta_{\max }, V_{\text {max }}$ は，そ れぞれ鉛直壁位置での通過波の最大水位と最大流速であ る. $F r_{\text {max }}$ は通過波の水位と, 同時計測された流速データ
から求められたFr数の最大值である。 また，通過波の最 大水位 $\eta_{\max }$ が発生する時刻におけるFr数を示す．さらに 参考のため, $F r^{\prime}$ も示寸。これは発生時刻が異なるもの の最大水位 $\eta_{\max }$ と最大流速 $V_{\max }$ により求めた $F r$ 数である

最も小さい $H=6 \mathrm{~cm}$ のースで, $F r_{\max }$ 方津波先端部で発 生しており，およそ2.0であった。林・越村5によれれ゙， 仙台平野を遡上する津波のFr数はおよそ2程度と報告さ れている．また，松富・原田のよれば最大浸水深から 推定された現地津波のFr数は $0.42 〜 1.2$ と報告されており， 本研究は，これらの上限值に近い条件に相当している.

\section{3. 実験結果と考察}

\section{(1) 衝撃波圧から持続波圧への波圧変化過程}

図-3は，貯水位 $H=9 \mathrm{~cm}$ のケースの波圧の時間変化を示 している．上段の図は，衝撃波圧から持続波圧を含む時 間を示しており，下段の図は，上段の図の1.5〜1.9 sを拡 大したもので，衝撃波圧のみを表示したものである.

上段の図を見ると，最下部のPS1で大きな衝撃波圧が 発生しており，その後いったん圧力が低下して，1.9 s以 降は全ての波圧センサがほぼ等間隔を維持しながら継続 している．1.9 s以降は，主に鉛直壁前面における水位の 上昇による静水圧が支配的となっている時間帯であり，

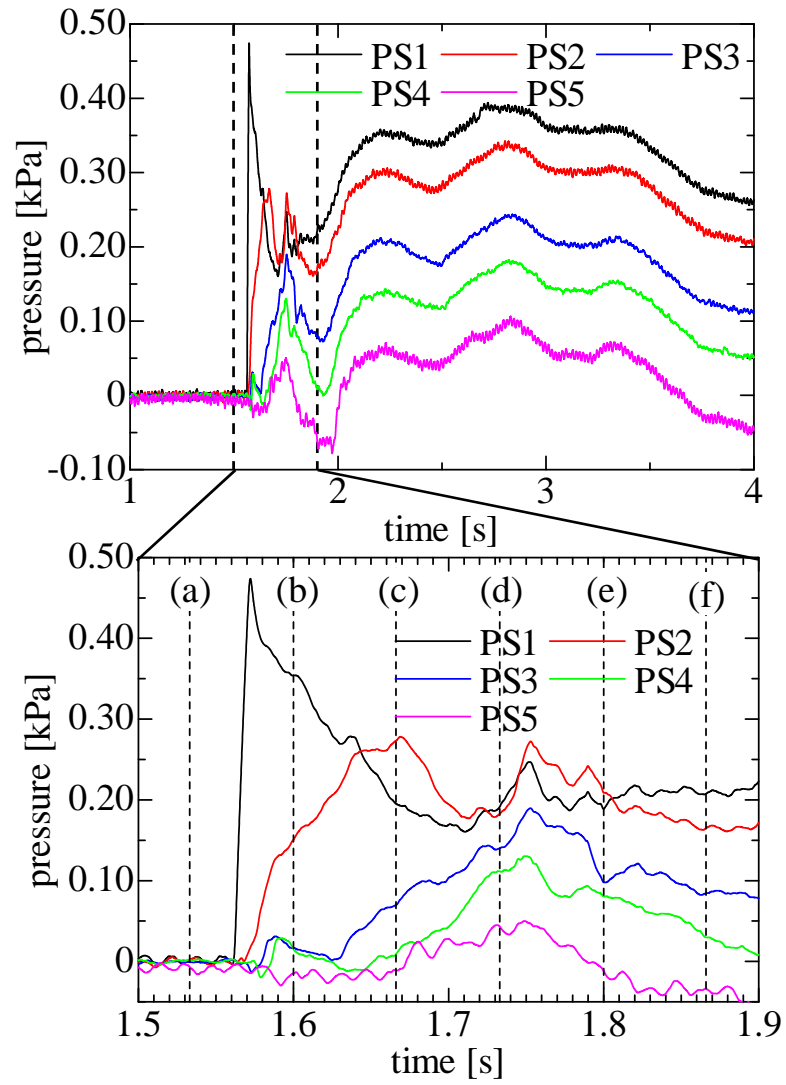

図-3 波圧の時間変化（貯水位 $H=9 \mathrm{~cm} ）$ 上段 : 衝撃波圧 から持続波圧を含む，下段 : 衝撃波圧のみ 
持続波圧と呼ばれている. 衝撃波圧と持続波圧の大小関 係は，衝突流速と構造物前面の浸水深によって決まる.

下段の図を見ると，PS1は衝撃波圧発生後に一度低下 するが，遅れてPS2が上昇し，時刻1.65 s以降でPS1とPS2 が逆転している．つまりこの時間帯では，最大波圧が最 下部に発生せず，少し上部に移動する．続いて，PS3〜 PS5がさらに遅れて上昇し，時刻1.76 sでPS1〜PS5が全て 極大值を示している。これらの傾向は，松冨らわによっ ても波圧と水位の時系列から同様の傾向が示されており， 本研究においても值の大小関係が異なるものの，基本的 な変動パターンはH=6〜 $12 \mathrm{~cm} の$ 全てのケースに現れたこ とから，組織的な流体運動によるものと考えた.

\section{(2) 内部流速場と圧力の時系列の関係}

図-4は，図-3の下段図に示した(a)〜(f)の時刻に対応し た鉛直壁前面における内部流速べクトルの変化である. 各図の右端には鉛直壁があり，津波は左側より入射する. 水平床の位置は $\mathrm{z}=-10 \mathrm{~mm}$ 高さであり，右端の水色の 四角は各波圧センサ(直径 $6 \mathrm{~mm}$ )の大きさと位置を示して
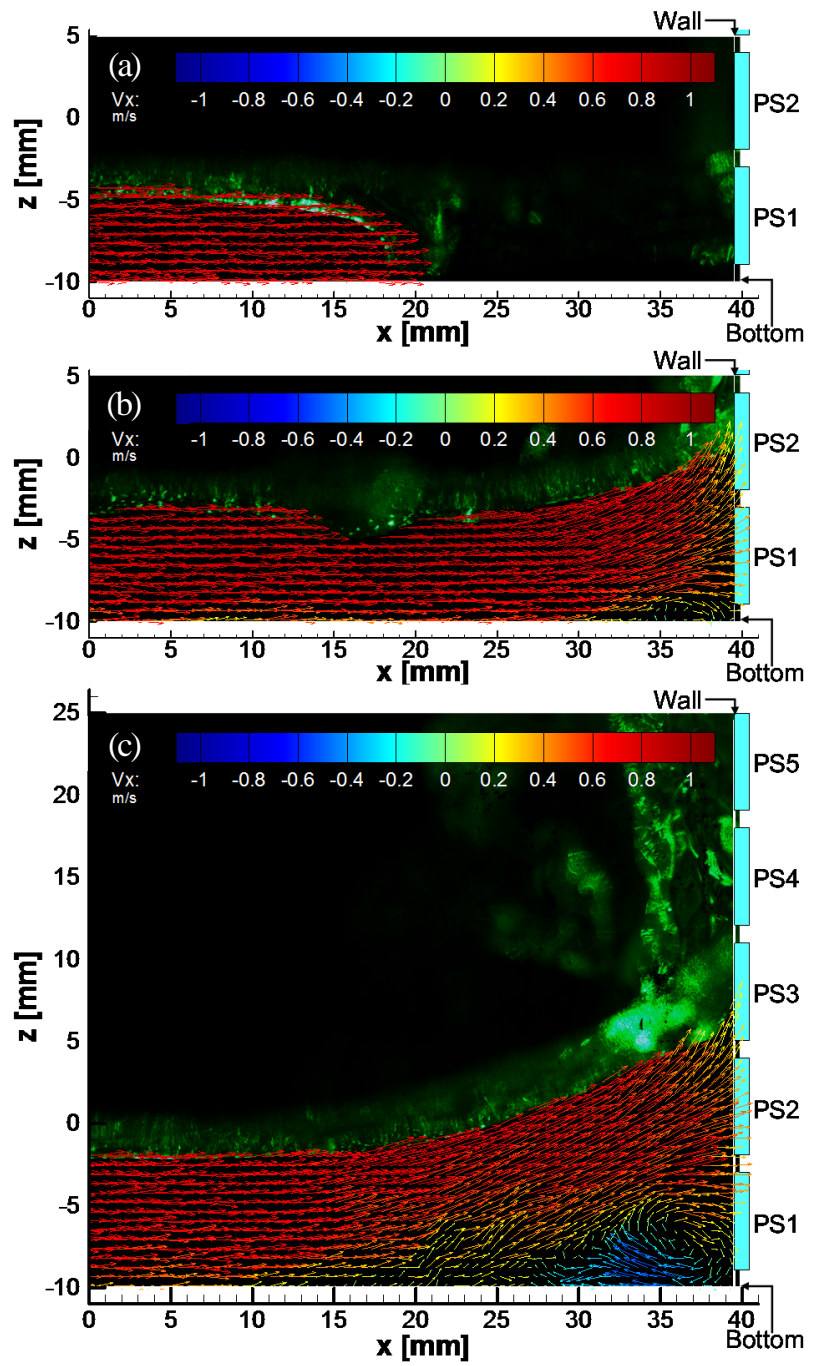

いる．また，ベクトルの色は流速の水平成分 $V_{x}$ の值を表 しており，暖色系は壁に向から流れ，寒色系は反転して 沖へ向から流れを示している. 前述のように流速ベクト ルは0.28 mm間隔で算出したが，ここでは見やすくする ためにベクトルを間引いて $0.56 \mathrm{~mm}$ 間隔で表示した.

(a)の図は，津波が壁に衝突する直前の状態である．先 端部の水位は約 $5 \mathrm{~mm}$, 流速は約 $0.8 \mathrm{~m} / \mathrm{s}$ であり，先端部は 底面近傍を除いて，ほぼ全域が同じ速度で進行している。

(b)の図は，壁に衝突した直後であり，図-3における時 刻1.6 s となる。主流が壁に衝突した後，水面付近の流れ が上方に転流しつつあり，水平床と鉛直壁の隅角部付近 には幅約 $5 \mathrm{~mm}$, 高さ約 $2 \mathrm{~mm} の$ 扁平な渦が形成されてい る. 津波が鉛直壁に衝突して隅角部で衝撃波圧が発生す ると，底面に沿って壁に向から圧力勾配は $d p / d x>0$ とな って主流を減速させる逆圧力勾配となる。この結果，主 流の減速が起こり，よどみ点で主流が底面から剥離して，
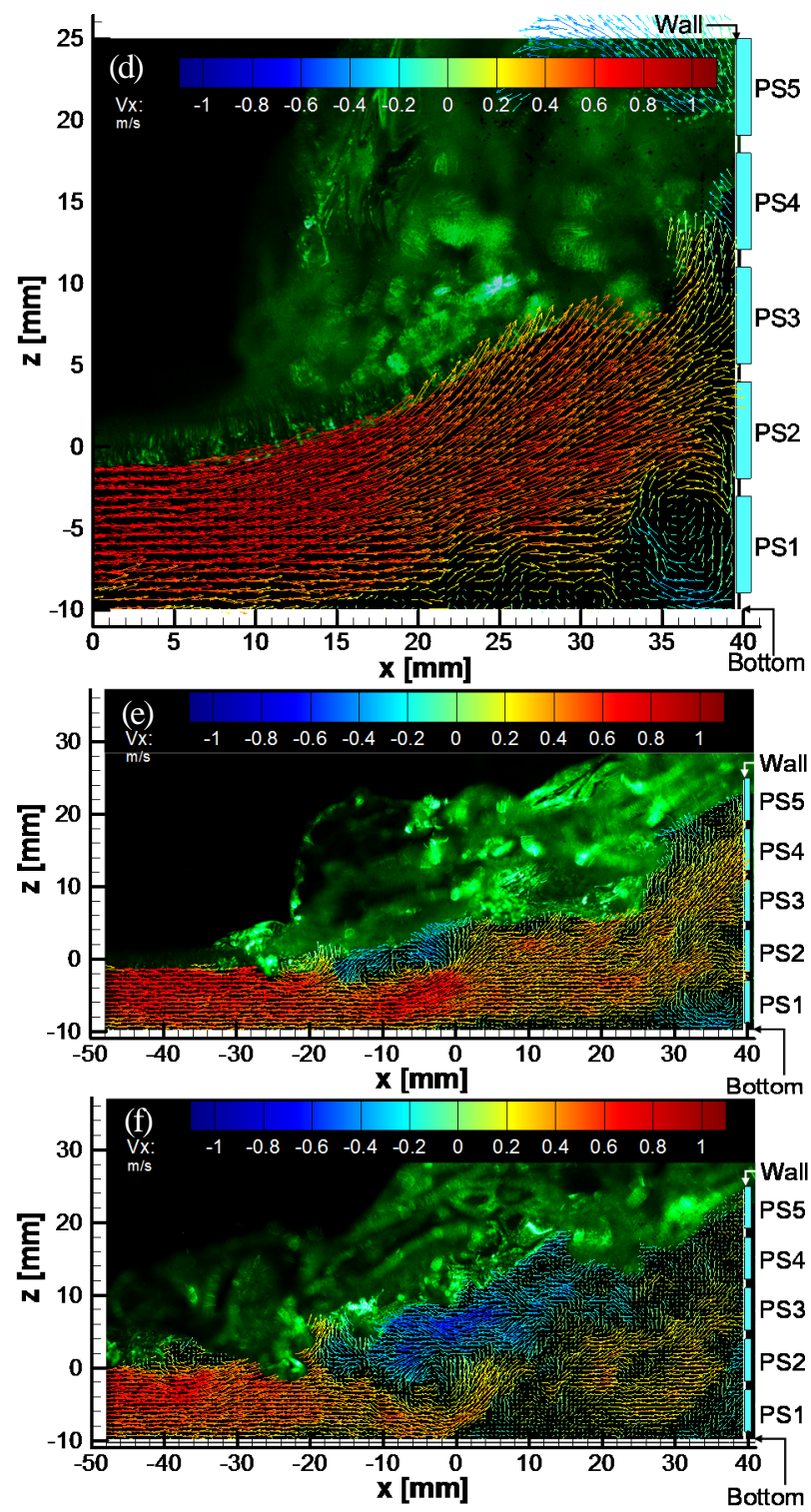

図-4 図-3 の時刻に対応した衝突直後の鉛直壁前面の内部流速ベクトルの分布（貯水位 $H=9 \mathrm{~cm} ）$ 
その下流側で剥離渦が発生したものと考えられる8.

(c)の図になると隅角部の渦が発達し，PS1の前面を覆 うほどになる。 この結果, 剥離した主流はこの渦の上部 を流れ，PS2に直接衝突することから，図-3で見られた ようにPS1とPS2では波圧の逆転現象が生じている.

続く(d)の図では，主流の水位が上昇し，さらに上方 に転流してPS2，PS3に直接衝突している．隅角部の渦 は，(c)よりも上方に転流している主流の影響を受けて鈆 直方向に伸長されている. ベクトル図の背景として水塊 の画像を示しているが，壁に衝突して打ち上がった水塊 が前面に着水する瞬間であると思われる，ただし，落水 が主流と混合するには至っていない.

(e)の図では，落水と主流が混合した直後である(他の 図とは表示範囲が異なるので, 現象のスケールに注意さ れたい)。この時刻において隅角部の渦はまだその形を 保っているが，流速場は全体的に減速しており，速い水 平流速(赤いい゙クトル)を持つ主流は $x=0 \mathrm{~mm}$ までしか達し ていない. 続く(f)の図では, 落水した水塊は沖に向かっ て流れるため, その先端付近，つまり鉛直壁から離れた 場所で主流と落水とが混合している。これにより主流は 鉛直壁には到達せず，鉛直壁には動圧が作用しないこと から，これ以降は，浸水深が支配的となる持続波圧の状 態になると考えられる.

(d)の図と(e)の図の間に打ち上がった水塊が落水するこ とによって，主流を混合する瞬間があり，図-3では全て の波圧センサが極大值を同時に示寸時刻 $1.76 \mathrm{~s}$ に一致す ると考えられる.

松冨ら》は，構造物前面の水位と波圧の時系列変化か ら, 打ち上がった水塊が落水して主流を遮断し, その後, 主流が再び衝突することで波圧の極大值が現れると推測 した. また，大村ら9もも打ち上がった水塊が落水し，構 造物前面の水位が低下寸る過程で全ての波圧が極大值を 示寸ことを明らかにしており，その瞬間に構造物に作用 する波力が最大になることを示している.

図一5は，波圧が極大值を示寸時刻にほぼ一致する時刻 の鉛直壁前面の内部流速べクトルの分布である. 貯水位 $H=9 \mathrm{~cm}$ のースであるが，図-4で示したケースではなく， 3回実施したうちの別のケースである.

図-5を見ると， $x=18 \mathrm{~mm}$ 付近を中心に $V_{x}$ が小さくなっ ており，主流が遮断されているようにも見える.しかし， 上からの落水によって主流が遮断されているようには見 えず，むしろ隅角部の渦の発達とともに底面付近の低速 な流速領域が上流側に拡大寸ることで主流が遮断されて いるようにも見える. 水谷ら行，打ち上がった水塊が 上昇速度を弱め，ほぼ最大水位となる時刻に波圧が極大 值となることを示しており, 図-5の時刻は, 打ち上がっ た水塊が上方への加速度を失い, 水位の全てが静水圧と して作用した瞬間を示寸ものではないかと考えられる.

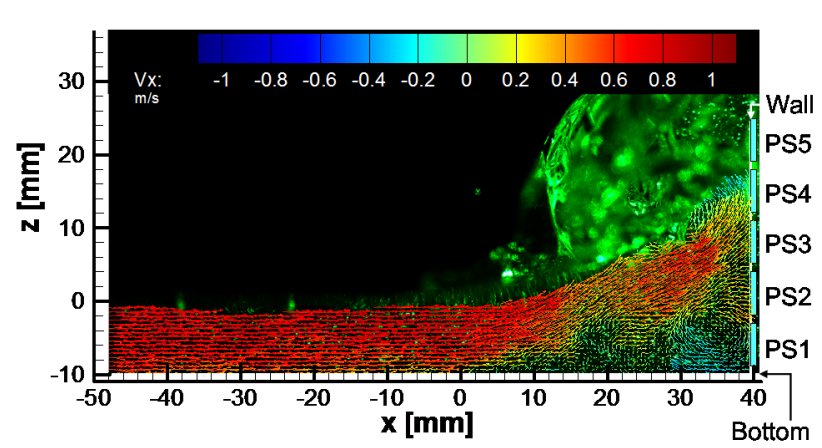

図-5 波圧の極大值が発生する時刻における鉛直壁前面の 内部流速ベクトルの分布

(貯水位 $H=9 \mathrm{~cm}$ ，ただし，図-4 とは別のケース)

これまでのところで，衝撃波圧から持続波圧一の遷移 過程を明らかにしたが，ここで工学的に重要となる点は 次の二点である. 一点目は, 主流の衝突が隅角部の渦の 形成によって上方に移動する点である.つまり最下部に 生じる衝撃波圧よりは小さくなるものの, より上部に生 じる衝撃波圧は，構造物に対する転倒モーメントを増大 させることから，その大きさを評価する必要がある．本 研究における津波の先端水位は約 $5 \mathrm{~mm}$ であり，これが 現地において $50 \mathrm{~cm}$ であると仮定すると，現地において1 〜2mの高さまで衝撃波圧に備えなければならない.

二点目は衝撃波圧から持続波圧への遷移過程において, 打ち上がり水塊の落水時刻に波圧の極大值が発生する. 構造物に対寸る波力はその瞬間に最大となる場合がある ことから，その值について評価する必要がある.

\section{(3) 衝撃波圧と衝突流速の関係}

図-6は波圧センサPS1 とPS2における衝撃波圧 $P_{i}$ を通過 波の最大流速 $V_{\text {max }}$ で無次元化し，Fr $r_{\max }$ で整理したもので ある. 図は6回の平均值を示寸.

水平床からセンサの中心まで4mmであるPS1は，全て のケースで津波が直接水平衝突した. 波圧の計測は, 各

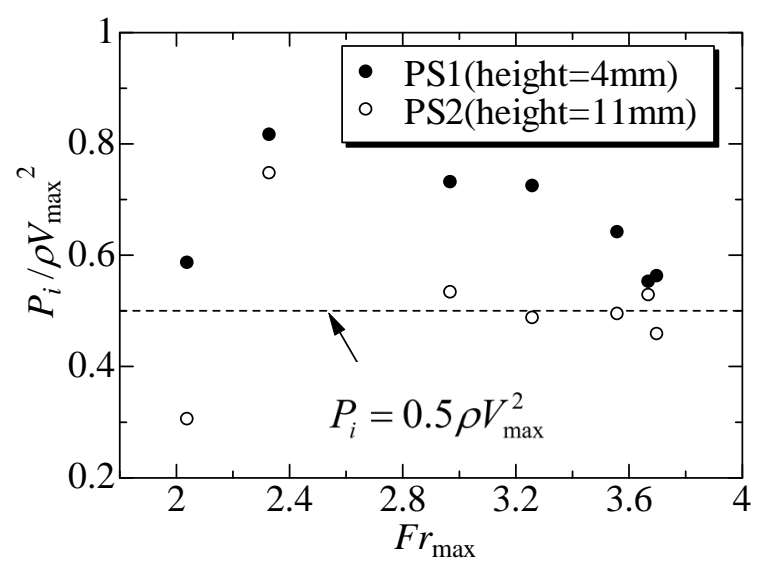

図-6 通過波の最大流速 $V_{\max }$ で無次元化した衝撃波圧と 最大 $F r$ 数の関係 
ケース6回実施したが，衝撃波圧はセンサに対する津波 のわずかな衝突角の変化によって值が大きく変化し, 変 動が大きかった． Fr $r_{\text {max }}=2.04 の$ ケースを除いて $F r_{\text {max }}$ が大き くなるほじ無次元衝撃波圧は小さくなる傾向にあるが, その理由は分からない. 個々のケースの無次元衝撃波圧 は最大で0.92となるものもあり, 有光らががした運動 量を考慮したモデル式をサポートすると考えられる.

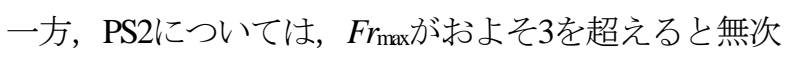
元衝撃波圧がほぼ 0.5 となっている. この結果は水谷ら4 が示した衝突波圧の結果とほぼ一致しており，PS2につ いては鉛直方向に衝突角が生じることから，最大衝撃波 圧発生時の衝突角 $\theta$ はおよそ45度となる。しかしながら， PS2に生じる衝撃波圧は，津波が打ち上がる過程で生じ るものであり，打ち上がり水塊による静水圧を加味する 必要があることから，相対的に水位の影響が大きくなる 低Fr数のケースについてはさらに検討が必要である.

\section{(4) 波圧の極大値と最大波力の発生について}

図-7は，PS1〜PS5までの各波圧センサの值を鉛直方向 に積分した単位幅当たりの水平波力の時間変化である.

比較のために貯水位 $H=8 \mathrm{~cm}$ のースについては, 幅10 cmの模型を側壁に沿って設置した場合の結果を併せて 示す. 水路幅 $40 \mathrm{~cm}$ に対して鉛直壁の幅が $10 \mathrm{~cm}$ なため, 津波が衝突した後は鈆直壁前面の水位が大きくは上昇せ ず，持続波圧が小さくなる場合である.

各矢印で示寸波力の極大值が，これまで示してきた波 圧の極大值の発生時刻に対応している. 津波が衝突して 衝撃波圧が発生した後, 持続波圧に遷移する前に極大波 力が発生していることが分かる. 貯水位 $H=8 \mathrm{~cm}$, 鉛直 壁幅10 cmのケースを見ると, 前面水位の上昇が小さけ れば持続波圧は大きくならず，ここで対象としている極 大波力が最大波力となる場合があることを示している.

次に各ケースの極大波力の絶対值について検討寸る必 要があるが，本研究で用いた波圧センサは5個しかなく， 打ち上がり水位を全てカバーできていない. 図-7はPS1 〜PS5までの波圧の積分值であることから，絶対值を評 価することができないため, 図-8に極大波力発生時にお

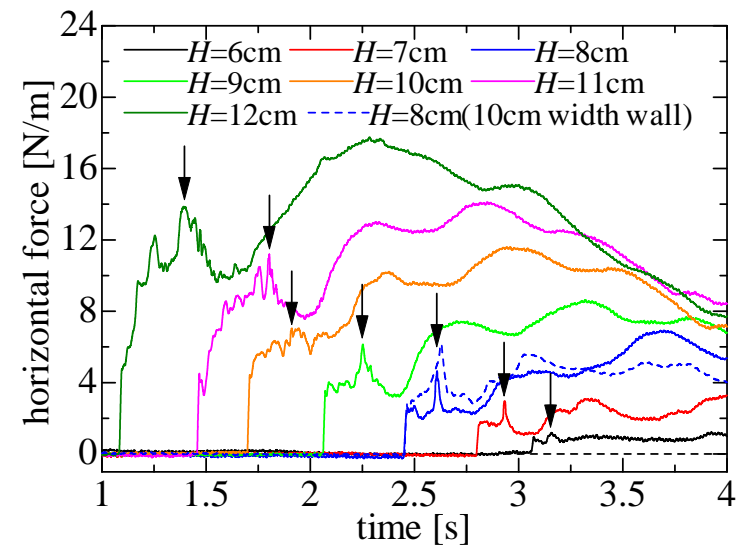

図-7 5 つの波圧を鉛直積分した単位幅当たりの水平波 力の時間変化

ける波圧の鉛直分布を示寸。

図-8は極大波力発生時の波圧の鉛直分布と同時刻の打 ち上がり水位による静水圧分布である. 同じ色で示す丸 印と直線は同時に計測された波圧の值と静水圧分布であ る. また破線は通過波の最大水位 $\eta_{\text {max }}$ の3倍の静水圧分 布，3pg $\eta_{\max }$ である.

全体的な傾向を見ると，PS2〜PS4では静水圧より波 圧が大きく, 隅角部の渦の形成によって主流の衝突が上 方に移動し, 動圧の影響が現れていると考えられる. 結 果的に貯水位 $H=9 \mathrm{~cm}$ 以上では, PS2〜PS4で鉛直方向に ほぼ一定の圧力分布となっている.

逆に, 貯水位 $H=8 \mathrm{~cm}$ ケースではPS1が, $H=9 \mathrm{~cm}$ 以上 のケースでは, PS1，PS2がほぼ静水圧分布に一致して おり，これはPS1の前面に大規模な渦が形成されること から, 衝突流速の動圧分が作用せず，打ち上がり水位に よる静水圧のみが作用していると理解することができる.

\section{4. 結語}

本研究では，鋁直壁に作用する陸上遡上津波の内部流 速場を可視化計測し, 波圧や水位の同時計測結果から， 内部流速場と波圧の遷移過程との関係について検討を行 った. 主要な結論を以下に示寸.

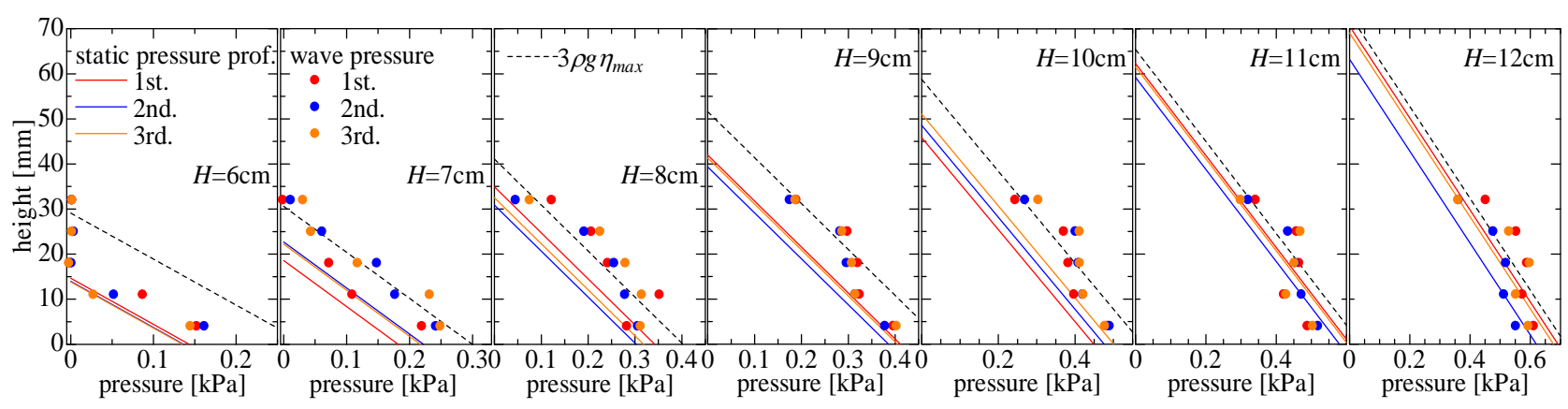

図-8 極大波力発生時の波圧の鉛直分布と同時刻の打ち上がり水位による静水圧分布 
1) 遡上津波の先端が鉛直壁に衝突した直後から鉛直壁 と水平床との隅角部に大規模な渦が形成され，それ が主流を上方へ移動させることが分かった。

2）大規模渦による主流の上方への移動によって衝撃波 圧が底面付近から時間遅れを伴って上部にも順次作 用することが分かった。

3）鉛直壁に衝突した津波が打ち上がり，それが落水す る時刻に全ての波圧センサが極大值を示した。また， その時に水平波力が極大となることが分かった．鉛 直壁の前面水位が大きくならない構造物においては, この波力が最大となる場合があることが分かった.

4) 水平波力が極大となる時刻の波圧分布から，底面付 近の波圧はその時刻の静水圧に一致し，それより上 部では主流流速による動圧の作用を受けて静水圧よ りも大きくなることが分かった.

今後の課題として，鉛直壁と水平床との隅角部に生じ る渦の大きさや持続時間について明らかにする必要があ る. これらはレイノルズ数に依存すると考えられるが, 現地のレイノルズ数と本研究におけるレイノルズ数は $10^{3}$ の隔たりがある. 木原ら ${ }^{10}$ の大規模水槽における実験 においても底面付近の圧力の低下が示されており，渦の 存在が示唆されるが，大規模実験においても内部の流速 場について検討を行う必要があると考えられる.

また，本研究で示した渦については，PIVの撮影間隔 が15Hzであることから，渦の生成から消滅まで3〜4枚し か捉えることができなかった。 しかも発生した渦は非定 常現象であるため, 渦スケールなどの定義が難しく, ケ 一ス毎の比較は再現性の高い実験を繰り返し行って, 平 均值の時間変化を比較しなければならない，これについ ても今後の課題としたい.
謝辞：本研究は日本学術振興会科研費（基盤(B)： 25282113，代表 : 水谷夏樹）による助成を受けた。ここ に謝意を表す。

\section{参考文献}

1) 松富英夫：砕波段波衝突時の圧力分布と全波力，海 岸工学論文集, 第 38 巻, pp.626-630, 1991.

2) 榊山勉：陸上遡上津波の伝播と構造物に作用する津 波波圧に関する研究，土木学会論文集 B2 (海岸工学), Vol.68, No.2, pp.I_771-I_775, 2012.

3) 有光剛, 大江一也, 川崎浩司：陸上構造物前面の浸 水深を用いた津波波圧算定式の提案，土木学会論文 集 B3 (海洋開発)，Vol.68，No.2， pp.I_13-I_18， 2012.

4) 水谷夏樹, 柳暁輝, 飯野佑樹, 宮島昌弘: 構造物前 面の流体現象に着目した津波波圧の特性，土木学会 論文集 B2(海岸工学), Vol.70, No.2, pp.I_836-I_840, 2014.

5) 林里美, 越村俊一: 映像解析による 2011 年東北地方 太平洋沖地震津波の流速測定, 土木学会論文集 B2(海 岸工学), Vol. 68, No.2, pp.I_366-I_370, 2012

6) 松富英夫, 原田賢治: 建物周りの津波痕跡分布とそ の活用一2009 年サモア地震津波を例に一, 土木学会 論文集 B2(海岸工学), Vol.66, No.1, pp.I_271-I_275, 2010.

7) 松冨英夫, 大向達也, 今井健太郎：津波氾濫流の構 造物一の流体力, 水工学論文集, Vol.48, pp.559-564, 2004.

8) 中林功一, 伊藤基之, 鬼頭修己 : 流体力学の基礎(2), コロナ社, pp.33-37, 1993.

9）大村智宏，八木宏，中山哲嚴，森健二，河野大輔， 加藤広之, 門安量, 滑川順 : 胸壁に作用する非越流 時の津波波力に関する実験的研究，土木学会論文集 B2(海岸工学), Vol.70, No.2, pp.I_881-I_885, 2014.

10）木原直人, 太田一行, 高畠大輔, 宮川義範, 松山昌 史：直立防潮堤に作用する津波波圧の大規模試験, 土木学会論文集 B2(海岸工学), Vol.70, No.2, pp.I_826-I_830, 2014.

(2015.3.18 受付)

\section{INTERNAL VELOCITY FIELD OF TSUNAMI ACTING ON A VAERTICAL WALL IN THE TRANSITION PROCESS FROM IMPACT WAVE PRESSURE TO SUSTAINED WAVE PRESSURE}

\section{Natsuki MIZUTANI and Masahiro MIYAJIMA}

In this study, internal velocity fields of tsunami acting on a vertical wall were measured by PIV with measurements of wave pressure and surface elevation at the wall. A large scale vortex appears at the corner of the bottom of the wall. The main stream of tsunami avoids the vortex and then the acting point of the main stream moves up along the wall. As the result, the wave pressure values around the bottom of the wall correspond to the hydrostatic pressure value calculated by the surface elevation at that time. The wave pressure values above the vortex exceed the hydrostatic pressure values, because of the action of the dynamical pressure of the main stream of tsunami. When the splashed water falls down on the main stream, the all of wave pressure values have the maximal values. At that time, the horizontal wave force also has the maximal value. 